\title{
Subunit Arrangement in P2X Receptors
}

\author{
Lin-Hua Jiang, Miran Kim, Valeria Spelta, Xuenong Bo, Annmarie Surprenant, and R. Alan North \\ Institute of Molecular Physiology, University of Sheffield, Sheffield S10 2TN, United Kingdom
}

\begin{abstract}
ATP-gated ionotropic receptors (P2X receptors) are distributed widely in the nervous system. For example, a hetero-oligomeric receptor containing both $\mathrm{P} 2 \mathrm{X}_{2}$ and $\mathrm{P} 2 \mathrm{X}_{3}$ subunits is involved in primary afferent sensation. Each subunit has two membrane-spanning domains. We have used disulfide bond formation between engineered cysteines to demonstrate close proximity between the outer ends of the first transmembrane domain of one subunit and the second transmembrane domain of another. After expression in HEK 293 cells of such modified $\mathrm{P} 2 \mathrm{X}_{2}$ or $\mathrm{P} 2 \mathrm{X}_{4}$ subunits, the disulfide bond formation is evident because an ATP-evoked channel opening requires previous reduction with dithiothreitol. In the hetero-oligomeric $\mathrm{P}_{2} \mathrm{X}_{2 / 3}$ receptor the coexpression of doubly substituted subunits with wild-type partners allows us to deduce that the hetero-oligomeric channel contains adjacent $\mathrm{P} 2 \mathrm{X}_{3}$ subunits but does not contain adjacent $\mathrm{P} 2 \mathrm{X}_{2}$ subunits. The results suggest a "head-to-tail" subunit arrangement in the quaternary structure of $\mathrm{P} 2 \mathrm{X}$ receptors and show that a trimeric $\mathrm{P} 2 \mathrm{X}_{2 / 3}$ receptor would have the composition $\mathrm{P} 2 \mathrm{X}_{2}\left(\mathrm{P}_{2} \mathrm{X}_{3}\right)_{2}$.
\end{abstract}

Key words: P2X receptors; ATP-gated channels; subunit stoichiometry; disulfide bonds; ligand-gated channel; subunit order

\section{Introduction}

$\mathrm{P} 2 \mathrm{X}$ receptors are membrane ion channels gated by extracellular ATP. They are involved in synaptic transmission in the peripheral and central nervous systems (Norenberg and Illes, 2000; Khakh, 2001; North, 2002) and play a role in initiating certain primary afferent signals (Bleehen and Keele, 1977; Ding et al., 2000; Hamilton et al., 2002). The receptors are oligomers, probably trimers (Bean, 1990; Nicke et al., 1998; Ding and Sachs, 1999; Stoop et al., $1999)$, and there are seven subunits in vertebrate species ( $\mathrm{P} 2 \mathrm{X}_{1}-$ $\mathrm{P} 2 \mathrm{X}_{7}$ ). The $\mathrm{P} 2 \mathrm{X}_{2}$ and $\mathrm{P} 2 \mathrm{X}_{4}$ subunits are distributed widely in nervous tissue. A particular role for the $\mathrm{P} 2 \mathrm{X}_{3}$ subunit in the initiation of some forms of pain perception has been indicated recently by experiments with receptor antagonists (Honore et al., 2002a; Jarvis et al., 2002), antisense oligonucleotides (Honore et al., 2002b), and gene knock-outs (Cockayne et al., 2000; Souslova et al., 2000).

The response to ATP of some sensory neurons is not well reproduced by heterologous expression of any single P2X subunit, including $\mathrm{P}_{2} \mathrm{X}_{3}$. This led to the proposal (Lewis et al., 1995) that a hetero-oligomeric receptor containing both $\mathrm{P} 2 \mathrm{X}_{2}$ and $\mathrm{P} 2 \mathrm{X}_{3}$ subunits was expressed by these cells. This notion subsequently has found widespread support from biochemical (Radford et al., 1997) and functional approaches [trigeminal ganglion (Cook et al., 1997); nodose ganglion (Thomas et al., 1998); dorsal root ganglia (Burgard et al., 1999; Grubb and Evans, 1999; Ueno et al.,

Received June 2, 2003; revised Aug. 8, 2003; accepted Aug. 8, 2003.

This work was supported by the Wellcome Trust. We thank D. Estoppey and V. Porteous for cell culture.

Correspondence should be addressed to R. A. North, Institute of Molecular Physiology, University of Sheffield, Sheffield S10 2TN, UK. E-mail: r.a.north@shef.ac.uk.

M. Kim's present address: Liver Research Center, Brown University School of Medicine, 55 Claverick Street, Providence, RI 02903.

V. Spelta's present address: Vollum Institute, Oregon Health and Science University, Portland, OR 97201.

$X$. Bo's present address: Academic Department of Neurosurgery, Medical Science Building, Queen Mary, University of London, Mile End Road, London E1 4NS, UK.

Copyright $\odot 2003$ Society for Neuroscience $\quad 0270-6474 / 03 / 238903-08 \$ 15.00 / 0$
1999; Dunn et al., 2000; Lalo et al., 2001; Zhong et al., 2001; Petruska et al., 2002)]. Other examples of hetero-oligomeric P2X receptors also have been reported (for review, see North, 2002).

$\mathrm{P} 2 \mathrm{X}$ receptor subunits are considered to have intracellular $\mathrm{N}$ and $\mathrm{C}$ termini and two membrane-spanning domains (TMs). The first TM is near the $\mathrm{N}$ terminus (residues $30-50$ in the $\mathrm{P}_{2} \mathrm{X}_{2}$ subunit), and the second TM begins close to residue 330. Most of the protein is formed by the intervening ectodomain; this has five conserved intrinsic disulfide bonds (Clyne et al., 2002; Ennion and Evans, 2002) as well as charged residues close to TM1 and TM2 that play a role in ATP binding (Ennion et al., 2000; Jiang et al., 2000). There is evidence that TM 2 contributes some residues to the ion permeation pathway (Rassendren et al., 1997; Egan et al., 1998), and both TMs are known to be major determinants of desensitization in P2X receptors (Werner et al., 1996); however, there is no information regarding the relative arrangement of the TMs within a subunit, and the quaternary organization of subunits within a receptor is unknown.

We investigated these questions by introducing cysteine residues that can form intersubunit disulfide bonds; when channels were expressed in human embryonic kidney (HEK) 293 cells, the reducing agents increased the ATP-evoked currents. From the pattern of the responsive substitutions we deduce that the homooligomeric $\mathrm{P}_{2} \mathrm{X}_{2}$ or $\mathrm{P} 2 \mathrm{X}_{4}$ receptors have an ordered "head-totail" orientation of subunits (i.e., TM1 of one subunit is adjacent to TM2 of the next) and that the $\mathrm{P} 2 \mathrm{X}_{2 / 3}$ hetero-oligomeric channel contains adjacent $\mathrm{P} 2 \mathrm{X}_{3}$ subunits, but not adjacent $\mathrm{P} 2 \mathrm{X}_{2}$ subunits.

\section{Materials and Methods}

Molecular and cell biology. The single and double cysteine mutant rat $\mathrm{P} 2 \mathrm{X}_{2}$ receptors were made in our previous studies (Rassendren et al., 1997; Jiang et al., 2001; Spelta et al., 2003). The single and double cysteine mutant $\mathrm{P}_{2} \mathrm{X}_{3}$ receptors were made with the same protocols as for the $\mathrm{P} 2 \mathrm{X}_{2}$ mutant receptors. The wild-type and mutant $\mathrm{P} 2 \mathrm{X}_{2}$ and $\mathrm{P} 2 \mathrm{X}_{3}$ subunits were transiently expressed in HEK 293 cells with Lipofectamine 
2000 (Invitrogen, San Diego, CA) as described previously (Spelta et al., 2003). Subunits tagged at their $C$ termini with the EMYPME epitope were used for Western blotting on SDS-PAGE as described (Kim et al., 2001). Samples that were applied were not denatured.

Electrophysiological recording. Whole-cell recordings were made at $20-$ $22^{\circ} \mathrm{C}$ at $24-72 \mathrm{hr}$ after transfection (Jiang et al., 2001). The holding potential was $-60 \mathrm{mV}$. The extracellular solution contained (in $\mathrm{mM}$ ): 147 $\mathrm{NaCl}, 2 \mathrm{KCl}, 2 \mathrm{CaCl}_{2}, 1 \mathrm{MgCl}_{2}, 10 \mathrm{HEPES}$, and 13 glucose, and the intracellular (pipette) solution comprised (in mM): $147 \mathrm{NaCl}$ or $\mathrm{NaF}, 10$ HEPES, and 10 EGTA. All solutions were maintained at $\mathrm{pH} 7.3$ and 300-315 mOsm/l. Chemicals were purchased from Sigma (Poole, UK). Agonists and dithiothreitol were applied by using an RSC 200 system (Biological Science Instruments, Grenoble, France).

Isolation of current through $P 2 X_{2 / 3}$ hetero-oligomeric channels. When recordings are made from cells that have been transfected with both $\mathrm{P} 2 \mathrm{X}_{2}$ and $\mathrm{P} 2 \mathrm{X}_{3}$ subunit cDNAs, there is a response to ATP and $\alpha \beta$ meATP that is not observed in cells transfected with either subunit alone [the current elicited by $\alpha \beta$ meATP is sustained over several seconds (Lewis et al., 1995)]. However, the interpretation of such coexpression experiments is complicated because hetero-oligomeric channels are not formed exclusively; there is evidence for homo-oligomeric channels as well (Thomas et al., 1998; Virginio et al., 1998). We determined the appropriate ratio of plasmids for cotransfection experiments by testing a range of ratios and subsequently measuring the expression by Western blotting (Kim et al., 2001) and by recording membrane currents. The $\mathrm{P} 2 \mathrm{X}_{2 / 3}$ receptor was activated by $10 \mu \mathrm{M} \alpha \beta \mathrm{meATP}$, which does not activate the wild-type $\mathrm{P} 2 \mathrm{X}_{2}$ receptor (Spelta et al., 2002) or the $\mathrm{P} 2 \mathrm{X}_{2}$ mutants that have been used here (data not shown). We consider that homo-oligomeric $\mathrm{P}_{2} \mathrm{X}_{3}$ receptors did not contribute substantive current in cotransfection experiments because we did not observe any fast-desensitizing component to the current with $10 \mu \mathrm{M} \alpha \beta$ meATP (see Fig. 1).

Data analysis. We applied four or five low agonist concentrations ([A]) noncumulatively to elicit small membrane currents ( $I$ ) (typically $2-10 \%$ but always $<20 \%$ of the peak current). When the current $I$ is much less than its maximal value $\left(I_{\max }\right)$ and $[\mathrm{A}]$ is much less than that causing one-half of the maximal effect $(K)$, then the Hill equation:

$$
I /\left(I_{\max }-I\right)=A^{n} /\left(K^{n}+A^{n}\right),
$$

reduces to:

$$
I=([A] / K)^{n} .
$$

For each cell we estimated the Hill coefficient $(n)$ by fitting a straight line by least squares to $\log (I)=n \log [\mathrm{A}]$; we present the mean value of these estimates with the SEM. For illustration (see Fig. 1) we also averaged the value of the current in all cells that were tested with a given concentration. Other results are shown as mean \pm SEM; tests for statistical significance were performed by using Student's unpaired $t$ test or ANOVA.

\section{Results}

\section{Hill slopes differ for homo-oligomeric and}

\section{hetero-oligomeric channels}

We used very low concentrations of agonists to estimate the initial slope of the concentration-response curve, because this estimate is less likely to be influenced by cooperative interactions among subunits and may indicate the number of ligand-binding sites (Fig. 1a). Figure $1 b$ shows that this was clearly less for the hetero-oligomeric $\mathrm{P} 2 \mathrm{X}_{2 / 3}$ than for the homo-oligomeric $\mathrm{P}_{2} \mathrm{X}_{2}$ and $\mathrm{P} 2 \mathrm{X}_{3}$ receptors. The slopes were $2.7 \pm 0.10(n=6), 2.5 \pm$ $0.14(n=5)$, and $1.7 \pm 0.14(n=5)$, respectively, for individual cells expressing $\mathrm{P} 2 \mathrm{X}_{2}$ [agonist $\mathrm{ATP} ; \mathrm{P} 2 \mathrm{X}_{2}$ receptors are not activated by $\alpha \beta$ meATP at the concentrations used in this study (Evans et al., 1995; North, 2002; Spelta et al., 2002)], P2X 3 (agonist $\alpha \beta$ meATP), and $\mathrm{P} 2 \mathrm{X}_{2 / 3}$ (agonist $\alpha \beta$ meATP) receptors. The values for $\mathrm{P} 2 \mathrm{X}_{2}$ and $\mathrm{P} 2 \mathrm{X}_{3}$ homomers are not different, but both of these are different from the value for the $\mathrm{P}_{2} \mathrm{X}_{2 / 3}$ hetero-oligomer (ANOVA, $p<0.001$ ). We cannot exclude the possibility that a

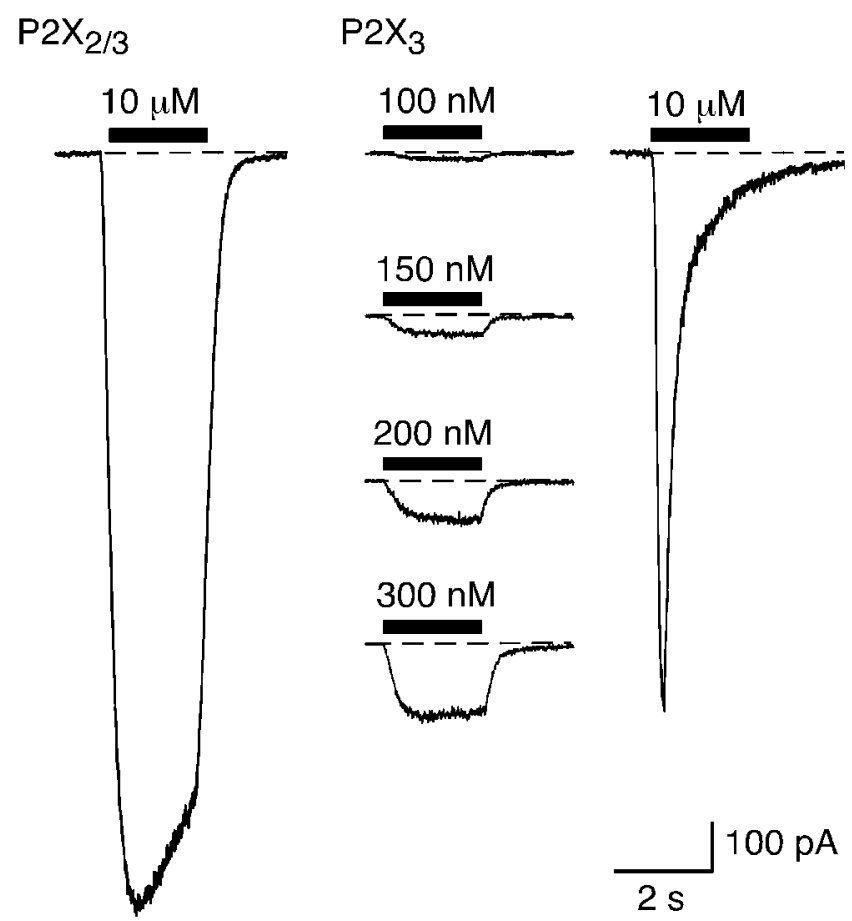

b

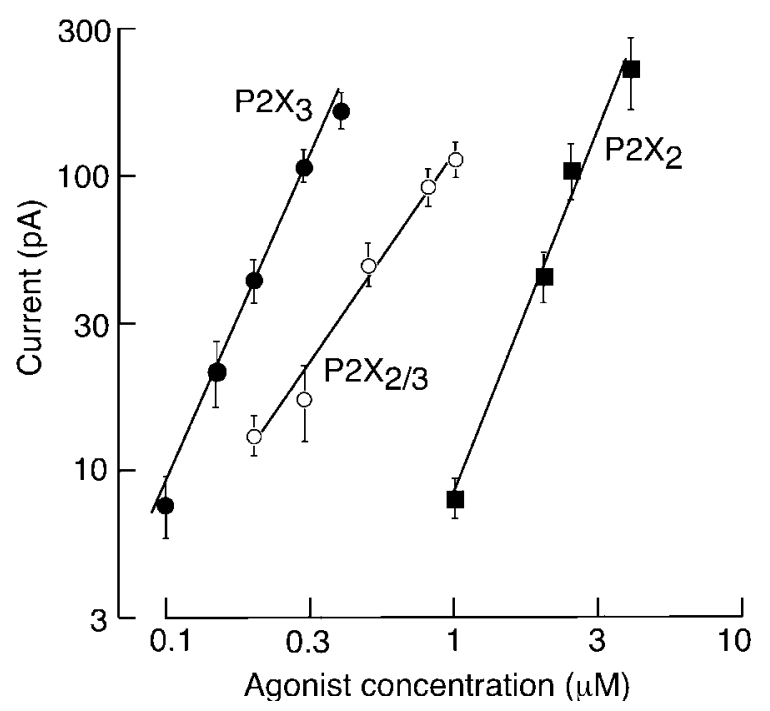

Figure 1. Distinct Hill slopes for activation of homo-oligomeric $\left(P 2 X_{2}\right.$ and $\left.P 2 X_{3}\right)$ and heterooligomeric (P2X $\left.X_{2 / 3}\right)$ receptors. a, Left, Representative currents evoked by $\alpha \beta$ meATP (10 $\left.\mu \mathrm{m}\right)$ in HEK 293 cells transfected with $P 2 X_{2}$ and $P 2 X_{3}$ subunits (1:5 ratio; see Materials and Methods). This is the concentration used in subsequent experiments on the cysteine-substituted receptors. Right, Typical currents evoked by $\alpha \beta$ meATP in HEK 293 cells transfected with P2X 3 subunits. At $10 \mu \mathrm{m}, \alpha \beta$ meATP evokes a rapidly rising and fast-desensitizing current that was not observed in the doubly transfected cells. At submicromolar concentrations the currents are sustained; such currents were used to estimate Hill coefficients. $b$, Currents were recorded from single cells held at $-60 \mathrm{mV}$ in response to increasing concentrations of agonists as indicated. ATP was used for $\mathrm{P} 2 \mathrm{X}_{2}$ (filled squares) and $\alpha \beta$ meATP for $\mathrm{P} 2 \mathrm{X}_{2 / 3}$ (open circles) and $\mathrm{P} 2 \mathrm{X}_{3}$ receptors (filled circles). The currents are presented as mean \pm SEM ( $n=4-6$ cells for each point). The slopes of these averaged lines are $P 2 X_{3} 2.28, P 2 X_{2 / 3} 1.46$, and $P 2 X_{2} 2.52$. 
a

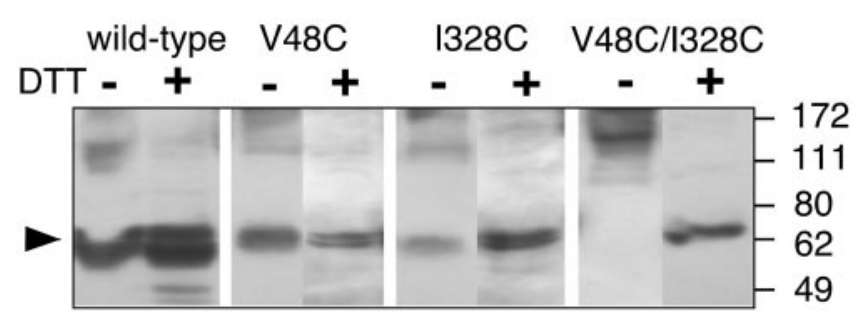

b
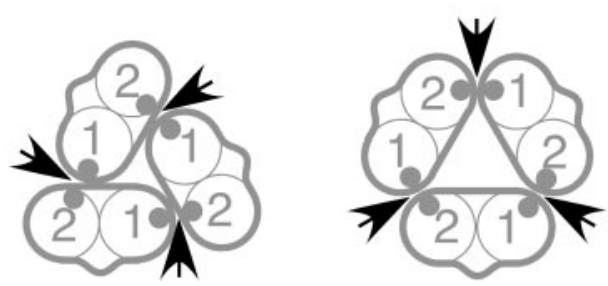

Figure 2. Intersubunit disulfide bond formation between V48C and I328C in the homooligomeric $\mathrm{P} 2 \mathrm{X}_{2}$ receptor. $a$, Wild-type $\mathrm{P} 2 \mathrm{X}_{2}$, single cysteine mutants $\mathrm{P} 2 \mathrm{X}_{2}[\mathrm{~V} 48 \mathrm{C}]$ and $\mathrm{P} 2 \mathrm{X}_{2}[\mathrm{I} 328 \mathrm{C}]$, and double mutant $\mathrm{P} 2 \mathrm{X}_{2}[\mathrm{~V} 48 \mathrm{C} / \mathrm{I328C}]$ subunits (each carrying a C-terminal EE epitope) were transiently expressed in HEK 293 cells. (ells were lysed in buffers with or without dithiothreitol as indicated. Protein samples were separated on SDS-PAGE gels and detected by Western blotting via an anti-EE antibody. The band indicated by an arrowhead corresponds to the expected size of the monomeric $\mathrm{P} 2 \mathrm{X}_{2}$ subunit; protein molecular weight markers are indicated on right. These results were observed in at least three independent experiments for each receptor. $b$, Schematic illustrations of the disulfide formation in homo-oligomeric $P 2 X_{2}$ receptors, assuming that the channel is a trimer. TM1 and TM2 of each subunit are indicated. Arrows indicate the positions of disulfide formation.

currents in cells expressing both $\mathrm{P} 2 \mathrm{X}_{2}$ and $\mathrm{P} 2 \mathrm{X}_{3}$ subunits pass through both homomeric $\mathrm{P}_{2} \mathrm{X}_{3}$ receptors and heteromeric $\mathrm{P} 2 \mathrm{X}_{2 / 3}$ receptors. Nonetheless, the difference between the homo-oligomeric and hetero-oligomeric forms is striking and suggests that the heterooligomeric $\mathrm{P} 2 \mathrm{X}_{2 / 3}$ receptor presents fewer $\alpha \beta$ meATP binding sites than the homo-oligomeric $\mathrm{P}_{2} \mathrm{X}_{3}$ receptor.

\section{Identification of an intersubunit disulfide bond}

Cysteine-scanning mutagenesis in and around the two TMs of the $\mathrm{P}_{2} \mathrm{X}_{2}$ receptor (Rassendren et al., 1997; Jiang et al., 2001; Spelta et al., 2003) has identified two positions that, when both are substituted by cysteine, could form a disulfide bond. After expression in HEK 293 cells the channels had very small responses to ATP, but this increased more than fivefold after dithiothreitol (DTT) or bis(2-mercaptoethyl)sulfone; the currents declined again when the reducing agent was removed (Jiang et al., 2001), suggesting that the two thiols spontaneously reoxidized. These two residues $\left(\mathrm{Val}^{48}\right.$ and $\mathrm{Ile}^{328}$ ) are situated near the extracellular ends of TM1 and TM2, respectively (Newbolt et al., 1998). None of 10 further pairs that were tested appeared to form similar disulfides (Spelta et al., 2003).

Our initial interpretation of these results was that a disulfide bond formed between cysteines provided by the two TMs of the same subunit (i.e., intrasubunit), but it is also possible that the disulfide forms between different $\mathrm{P} 2 \mathrm{X}_{2}$ subunits (i.e., intersubunit), implying that gating involves movements of the subunits relative to each other. We distinguished these possibilities by solubilizing the epitope-tagged $\mathrm{P}_{2} \mathrm{X}_{2}$ receptor after expression in HEK 293 cells. The wild-type subunits, and subunits containing either V48C or I328C substitutions alone, migrated on SDSPAGE predominantly at the position expected for the monomeric subunit $(\sim 62 \mathrm{kDa}$; arrowhead in Fig. $2 a)$. A smaller
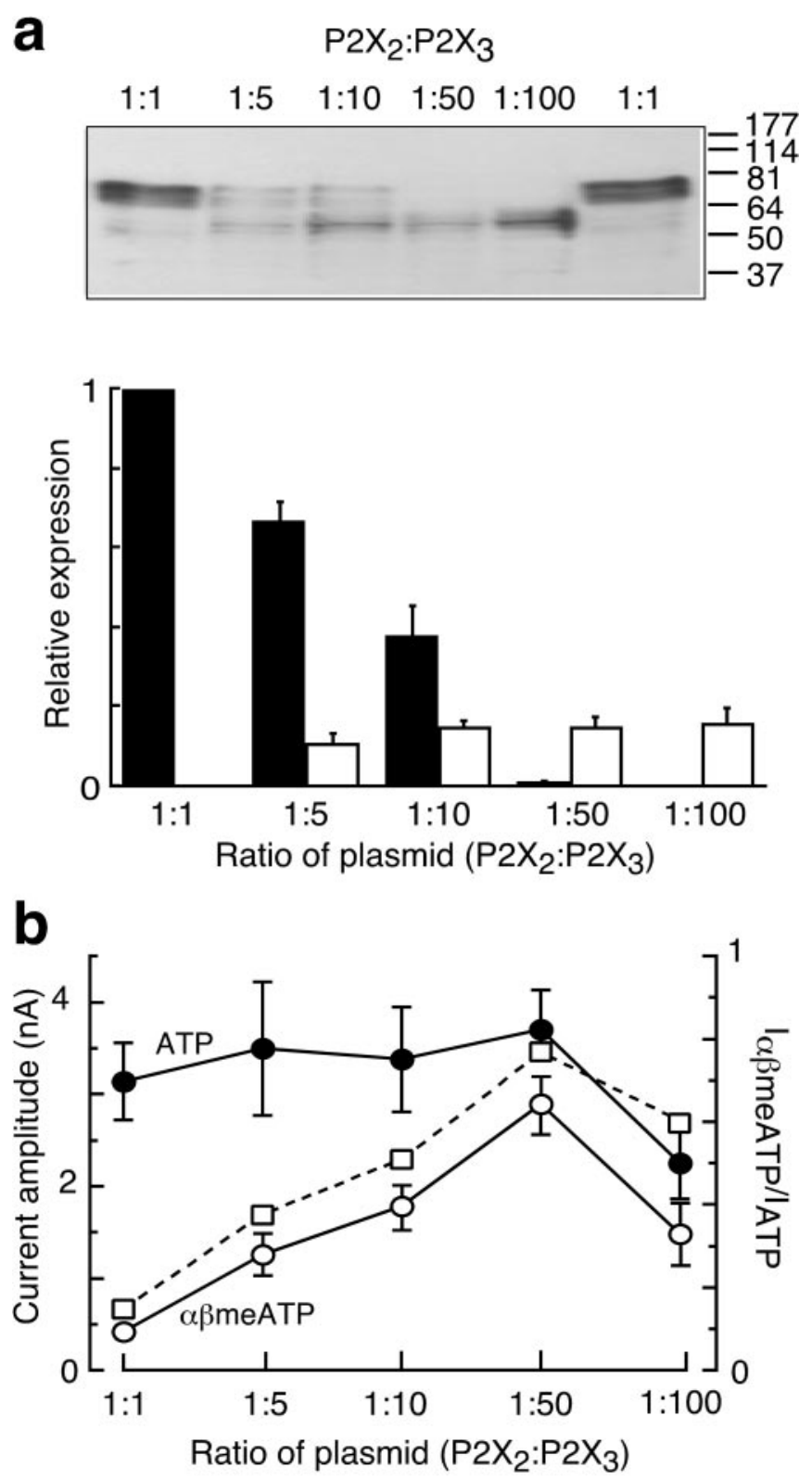

Figure 3. Coexpression of $P 2 X_{2}$ and $P 2 X_{3}$ subunits. $a$, Western blots on SDS-PAGE gel show the relative expression of the two subunits expressed in HEK 293 cells, each detected with the same C-terminal EE epitope antibody. The bottom panel shows the quantitation for such experiments from $x$-ray film densitometric analysis $(n=4) . b$, The currents elicited by ATP and $\alpha \beta$ meATP (left axis) and their ratio (right axis) are shown in HEK 293 cells transfected with various proportions of $\mathrm{P}_{2} \mathrm{X}_{2}$ and $\mathrm{P} 2 \mathrm{X}_{3}$ plasmids $(n=4-7)$. In all experiments $1 \mu \mathrm{g}$ of $\mathrm{P}_{2} \mathrm{X}_{3}$ plasmid was used, with 200, 100,20, or $10 \mathrm{ng}$ of P2X 2 plasmid; error bars indicate SEM.

amount of higher molecular mass form also was observed. In contrast, no monomeric form was observed for the subunit containing cysteines at both positions ( $\left.\mathrm{P}_{2} \mathrm{X}_{2}[\mathrm{~V} 48 \mathrm{C} / \mathrm{I} 328 \mathrm{C}]\right)$. The higher molecular mass protein that was observed presumably represents a disulfided dimer, because DTT reduced this to a monomeric size (Fig. 2a). DTT had no effect on the wild-type subunit or subunits with single cysteine substitutions (Fig. 2a), suggesting that the disulfide bond is predominantly intersubunit rather than intrasubunit. Moreover, in parallel experiments with $\mathrm{P}_{2} \mathrm{X}_{2}[\mathrm{~V} 48 \mathrm{C} / \mathrm{T} 336 \mathrm{C}], \mathrm{P} 2 \mathrm{X}_{2}[\mathrm{Q} 37 \mathrm{C} / \mathrm{L} 338 \mathrm{C}]$, and $\mathrm{P} 2 \mathrm{X}_{2}[\mathrm{~F} 44 \mathrm{C} /$ L338C] (Jiang et al., 2001; Spelta et al., 2003) a band corresponding to the monomer $(60-70 \mathrm{kDa})$ was observed clearly both in the 
absence or the presence of DTT (data not shown). We previously reported (Jiang et al., 2001) that ATP-evoked currents were unaffected by DTT in the case of $\mathrm{P}_{2} \mathrm{X}_{2}[\mathrm{~V} 48 \mathrm{C}]$ and $\mathrm{P} 2 \mathrm{X}_{2}[\mathrm{I} 328 \mathrm{C}]$ expressed alone, so these experiments all indicate that in the intact channel the disulfide forms between the TM1 of one subunit and the TM2 of another (Fig. 2b).

We have found similar results for the $\mathrm{P}_{2} \mathrm{X}_{4}$ receptor. ATP evoked only very small currents in HEK 293 cells expressing the double cysteine-substituted $\mathrm{P}_{2} \mathrm{X}_{4}$ receptor $\left(\mathrm{P} 2 \mathrm{X}_{4}[\mathrm{~V} 47 \mathrm{C} / \mathrm{I} 333 \mathrm{C}]\right)$. These currents $(59 \pm 16 \mathrm{pA} ; n=7)$ were increased 12-fold after a 4 min application of DTT ( $10 \mathrm{~mm}$; to $721 \pm 175 \mathrm{pA} ; n=7$ ). However, receptors with either cysteine substituted singly gave currents that were not different from those in cells expressing wild-type $\mathrm{P}_{2} \mathrm{X}_{4}$ receptors $(1589 \pm 812 \mathrm{pA}$; $n=4)$, and dithiothreitol had no effect $\left(\mathrm{P}_{4}[\mathrm{~V} 47 \mathrm{C}]: 1989 \pm 457 \mathrm{pA}, n=4\right.$; $\left.\mathrm{P}_{2 X_{4}}[\mathrm{I} 333 \mathrm{C}]: 2053 \pm 427 \mathrm{pA}, n=3\right)$.

\section{Head-to-tail disulfide formation between TMs in a hetero-oligomeric $\mathrm{P} 2 \mathrm{X}_{2 / 3}$ receptor}

In experiments on coexpression of $\mathrm{P}_{2} \mathrm{X}_{2}$ and $\mathrm{P} 2 \mathrm{X}_{3}$ subunits we first determined the appropriate plasmid ratio for transfection that would produce approximately equal membrane expression. Both densitometry of membrane protein (Fig. $3 a$ ) and functional experiments comparing ATP and $\alpha \beta$ meATP (Fig. $3 b$ ) indicated that the appropriate ratio was 1:5 or 1:10; we used a ratio of 1:5 in subsequent experiments.

Figure 4 shows that disulfides also can form between cysteines at the extracellular end of TM1 in the $\mathrm{P}_{2} \mathrm{X}_{2}$ subunit $\left(\mathrm{P} 2 \mathrm{X}_{2}[\mathrm{~V} 48 \mathrm{C}]\right)$ and the outer end of TM2 in the $\mathrm{P} 2 \mathrm{X}_{3}$ subunit $\left(\mathrm{P}_{2} \mathrm{X}_{3}[\mathrm{I} 319 \mathrm{C}]\right)$. Coexpression of these two forms resulted in currents evoked by $\alpha \beta \mathrm{meATP}(10 \mu \mathrm{M} ; 191 \pm 32 \mathrm{pA} ; n=9)$ that were much smaller than those seen with the wild-type heterooligomer, and these currents were increased threefold by dithiothreitol (Fig. 4b). The increase by dithiothreitol reversed on washout and could be repeated with a second application (Fig. $4 b$ ). A clear effect of dithiothreitol also was observed with coexpression of the two subunits with cysteines at the outer end of TM2 of the $\mathrm{P}_{2} \mathrm{X}_{2}$ subunit $\left(\mathrm{P}_{2} \mathrm{X}_{2}[\mathrm{I} 328 \mathrm{C}]\right)$ and the outer end of TM1 of the $\mathrm{P}_{2} \mathrm{X}_{3}$ subunit $\left(\mathrm{P} 2 \mathrm{X}_{3}[\mathrm{~V} 42 \mathrm{C}]\right)$. In this case the initial current was $432 \pm 122 \mathrm{pA}(n=3)$, and the increase in dithiothreitol was to $145 \pm 15 \%$ of this control value. In contrast, there was no effect of dithiothreitol on the currents evoked by $\alpha \beta$ meATP in cells expressing subunits with cysteines in both TM1s (i.e., of $\mathrm{P} 2 \mathrm{X}_{2}$ and $\mathrm{P} 2 \mathrm{X}_{3}$ ) or both TM2s or in cells coexpressing a wild-type subunit with a single cysteine-substituted subunit (Fig. 4). The effects of dithiothreitol on the nine pairs of subunits that were tested are summarized in Figure $5 a$, and the results are illustrated schematically in Figure $5 b$. They indicate that disulfide bridges can form only between the first TM of one subunit and the second TM domain of another. We cannot exclude the possibility that disulfide bonds can form with some of the other combinations that were tested, but we can say that, if they do, there is no effect on binding or gating of the channel at the macroscopic level.

Hetero-oligomeric channels have adjacent $P 2 X_{3}$ subunits, but not adjacent $\mathrm{P} 2 \mathrm{X}_{2}$ subunits

The specificity of the "crossed" disulfide formation with respect to TM1 and TM2, together with our observation that disulfides could form in the double cysteine homo-oligomeric $\mathrm{P} 2 \mathrm{X}_{2}$ receptor (Jiang et al., 2001) (Fig. 2b) and $\mathrm{P}_{2} \mathrm{X}_{4}$ receptor, led us to hypothesize that disulfide bonds would form between two adjacent copies of the same subunit within a hetero-oligomeric channel. We coexpressed wild-type $\mathrm{P}_{2} \mathrm{X}_{3}$ subunits with the double cysteine $\mathrm{P}_{2} \mathrm{X}_{2}$ subunit $\left(\mathrm{P}_{2} \mathrm{X}_{2}[\mathrm{~V} 48 \mathrm{C} / \mathrm{I} 328 \mathrm{C}]\right)$. The currents $(772 \pm 132 \mathrm{pA} ; n=14$ with $10 \mu \mathrm{M} \alpha \beta \mathrm{meATP})$ were not different from those of wild-type $\mathrm{P} 2 \mathrm{X}_{2 / 3}$ hetero-oligomeric channels, and DTT had no effect (Fig. $6 a$ ). Thus although the double cysteine $\mathrm{P}_{2} \mathrm{X}_{2}$ subunits can form DTT-sensitive disulfide bonds readily in the homo-oligomeric receptor (Jiang et al., 2001), they are unable to do so in the hetero-oligomeric complex. This implies either that there is only a single $\mathrm{P} 2 \mathrm{X}_{2}$ subunit or that multiple $\mathrm{P} 2 \mathrm{X}_{2}$ subunits are nonadjacent.

In marked contrast was the result of the converse experiment in which we coexpressed the wild-type $\mathrm{P} 2 \mathrm{X}_{2}$ subunit with the $\mathrm{P}_{2} \mathrm{X}_{3}$ subunit containing two cysteines. The currents evoked by $\alpha \beta$ meATP were only $\sim 10 \%$ of the control amplitude $(123 \pm 26$ 
a

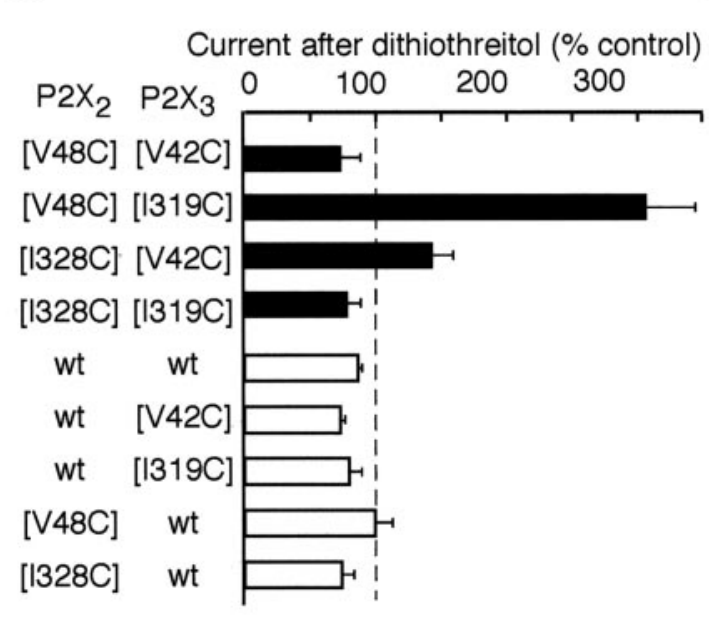

b

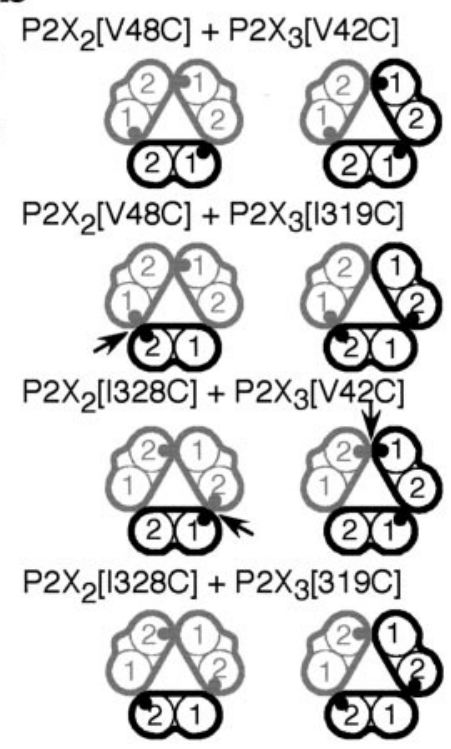

Figure 5. a, Summary of effects of DTT (10 mm, $12 \mathrm{~min})$ on $\alpha \beta$ meATP-evoked currents recorded from cells coexpressing different combinations of wild-type or single mutant $P 2 X_{2}$ and $P 2 X_{3}$ receptors ( $n=3-9$ cells for each combination). Filled bars represent forms with cysteines in both subunits. Actual currents in those seven combinations in which DTT had no effect included the following (pA \pm SEM for the number of cells in parentheses): $P 2 X_{2}[V 48 C]$ with $P 2 X_{3}[V 42 C], 1244 \pm 358$ (4); $P 2 X_{2}[1328 C]$ with $P 2 X_{3}[I 319 C], 404 \pm 61(4) ; P 2 X_{2}[V 48 C]$ with wild-type $P 2 X_{3}, 471 \pm 122(4) ; P 2 X_{2}[I 328 C]$ with wild-type $P 2 X_{3}, 840 \pm 215$ (4); wild-type $P 2 X_{2}$ with $P 2 X_{3}[V 42 C], 1399 \pm 468$ (3); wild-type $P 2 X_{2}$ with $P 2 X_{3}[I 319 C], 692 \pm 276$ (4); and wild-type $P 2 X_{2}$ with

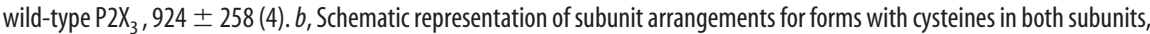
assuming that the channel is a trimer. Left, Channels containing one $P 2 X_{3}$ subunit (black). Right, Channels containing one $P 2 X_{2}$ subunit (gray). TM1 and TM2 of each subunit are indicated; cysteines that have been introduced are depicted by small filled circles. The arrows indicate the disulfides that have formed, based on an effect of dithiothreitol on the expressed currents.

value for the slope that was observed (1.7) for the hetero-oligomeric $\mathrm{P} 2 \mathrm{X}_{2 / 3}$ receptor must be interpreted in the context that at least two sets of channels might be present (homomeric $\mathrm{P} 2 \mathrm{X}_{3}$ and heteromeric $\mathrm{P} 2 \mathrm{X}_{2 /}$ $3)$; in this case the slope might represent a composite value, but any heteromeric channel or channels would have fewer than three binding sites for $\alpha \beta$ meATP.

The $\mathrm{P} 2 \mathrm{X}_{2}$ subunit containing two cysteine substitutions $\left(\mathrm{P}_{2} \mathrm{X}_{2}[\mathrm{~V} 48 \mathrm{C} / \mathrm{I} 328 \mathrm{C}]\right)$ behaved very differently on SDS-PAGE from the subunit containing one or neither (Fig. 2). Along with the striking effect of DTT, we interpret this to indicate that these cysteines can participate in intersubunit disulfide bond formation. The proximity of these two cysteines in the functioning channel is indicated by the finding that DTT causes a fivefold increase in the ATP-evoked currents in cells expressing $\mathrm{P}_{2} \mathrm{X}_{2}[\mathrm{~V} 48 \mathrm{C} / \mathrm{I} 328 \mathrm{C}]$ subunits but has no effect on channels formed from $\mathrm{P}_{2} \mathrm{X}_{2}$ [V48C], $\mathrm{P} 2 \mathrm{X}_{2}$ [I328C], or wild-type

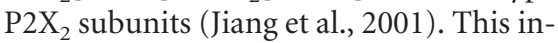
dicates that in the functioning channels these residues at the outer ends of TM1 and TM2 are close to each other; the distance from $\mathrm{C} \alpha$ to $\mathrm{C} \alpha$ calculated from bond lengths is $0.84 \mathrm{~nm}$. The finding that no disulfides were observed either biochemically (Fig. 2) or functionally (Jiang et al., 2001) with $\mathrm{P}_{2} \mathrm{X}_{2}[\mathrm{~V} 48 \mathrm{C}]$ or $\mathrm{P} 2 \mathrm{X}_{2}[\mathrm{I} 328 \mathrm{C}]$ further suggests that the subunits must be ar-

pA; $n=11$ ), and DTT evoked a threefold increase (Fig. 6b). The increase was sustained, reversed when the DTT was washed out, and was reproducible (Fig. 6). This result indicates that $\mathrm{P}_{2} \mathrm{X}_{3}$ subunits are sufficiently close in the hetero-oligomeric complex for disulfide formation and that this disulfide impedes channel gating. In other words, the channel contains at least two $\mathrm{P}_{2} \mathrm{X}_{3}$ subunits, and these have a head-to-tail arrangement (i.e., TM1 of one $\mathrm{P} 2 \mathrm{X}_{3}$ subunit is adjacent to TM2 of another).

\section{Discussion}

Estimates of the number of subunits in a $\mathrm{P} 2 \mathrm{X}$ receptor have been provided by biochemical approaches. Nicke et al. (1998) concluded that a trimer was a fundamental constituent form of the $\mathrm{P}_{2} \mathrm{X}_{1}$ (and $\mathrm{P}_{2} \mathrm{X}_{3}$ ) channels heterologously expressed in Xenopus oocytes on the basis of both cross-linking and nondenaturing gel electrophoresis. Functional approaches have provided estimates of the number of agonist binding sites. In his recordings from dorsal root ganglion cells, Bean (1990) examined the effects of different ATP concentrations and suggested that three molecules of ATP might be required to activate the channel. $\mathrm{P} 2 \mathrm{X}_{2}$ receptors expressed in oocytes exhibit single channel kinetics that are best fit by the assumption of three ATP molecules binding (Ding and Sachs, 1999), and experiments with concatenated $\mathrm{P}_{2} \mathrm{X}_{2}$ subunit cDNAs carrying functional reporter mutations are also consistent with a trimeric channel (Stoop et al., 1999). The simplest interpretation of our present results with low agonist concentrations is that the homo-oligomeric channel has three identical, independent binding sites. This would give an initial slope of three for the log-log plot, which is close to what we observed for both the homo-oligomeric $\mathrm{P} 2 \mathrm{X}_{2}$ and $\mathrm{P} 2 \mathrm{X}_{3}$ receptors (Fig. 1). The ranged in a head-to-tail manner in which contacts are made between the TM1 segment of one subunit and the TM2 segment of another. The findings on the $\mathrm{P} 2 \mathrm{X}_{4}$ subunit suggest that the principle of this organization can be generalized.

These observations set the stage for our experiments on the $\mathrm{P}_{2} \mathrm{X}_{2 / 3}$ hetero-oligomer. Our functional expression showed that DTT increased the membrane current so long as the cysteines were introduced into TM1 of $\mathrm{P} 2 \mathrm{X}_{2}$ and $\mathrm{TM} 2$ of $\mathrm{P} 2 \mathrm{X}_{3}$ or vice versa. The effect was smaller in the latter case $\left(\mathrm{P}_{2} \mathrm{X}_{2}[\mathrm{I} 328 \mathrm{C}]+\right.$ $\mathrm{P}_{2} \mathrm{X}_{3}[\mathrm{~V} 42 \mathrm{C}]$ ), and this might indicate that disulfide formation was incomplete, occurring in only a fraction of channels. In contrast, we found no evidence for interaction between $\mathrm{P} 2 \mathrm{X}_{2}$ and $\mathrm{P}_{2} \mathrm{X}_{3}$ subunits when each had cysteines introduced at the outer end of TM1 $\left(\mathrm{P} 2 \mathrm{X}_{2}[\mathrm{~V} 48 \mathrm{C}]+\mathrm{P}_{2} \mathrm{X}_{3}[\mathrm{~V} 42 \mathrm{C}]\right)$; current amplitudes were normal, and DTT had no effect. When both outer ends of TM2 were substituted $\left(\mathrm{P}_{2} \mathrm{X}_{2}[\mathrm{I} 328 \mathrm{C}]+\mathrm{P} 2 \mathrm{X}_{3}[\mathrm{I} 319 \mathrm{C}]\right)$, there was also no effect of DTT, although initial $\alpha \beta$ meATP currents were small. Each of these substitutions was well tolerated when the subunit was expressed singly (normal current amplitudes; data not shown) (see also Rassendren et al., 1997). These results are consistent with a head-to-tail arrangement of $\mathrm{P} 2 \mathrm{X}_{2}$ and $\mathrm{P} 2 \mathrm{X}_{3}$ subunits in the channel (Fig. 5b), as proposed above for the homo-oligomeric $\mathrm{P} 2 \mathrm{X}_{2}$ receptor. The difference in the effectiveness of DTT between $\mathrm{P}_{2} \mathrm{X}_{2}[\mathrm{~V} 48 \mathrm{C}]+\mathrm{P} 2 \mathrm{X}_{3}[\mathrm{I} 319 \mathrm{C}]$ (300\% increase) and $\mathrm{P}_{2} \mathrm{X}_{2}[\mathrm{I} 328 \mathrm{C}]+\mathrm{P}_{2} \mathrm{X}_{3}[\mathrm{~V} 42 \mathrm{C}]$ (50\% increase) is not unexpected, given that the nearby amino acids in these regions of the two subunits are not identical. The positions of the two reacting cysteines at the outer ends of the transmembrane domains are compatible with earlier studies with immunoprecipitation of chi- 
meric $\mathrm{P} 2 \mathrm{X}$ receptor subunits, which indicated that these domains were required for hetero-oligomer formation (Torres et al., 1999b). Such coimmunoprecipitation experiments have indicated that various other pairs of P2X subunits can associate with each other (Torres et al., 1999a), and it will be important to determine whether our approach with cysteine substitutions at the ends of TM1 and TM2 can be generalized to other pairs of different subunits.

The coexpression of $\mathrm{P} 2 \mathrm{X}_{2}$ and $\mathrm{P} 2 \mathrm{X}_{3}$ subunits each carrying a single cysteine substitution cannot distinguish between trimers containing one $\mathrm{P}_{2} \mathrm{X}_{2}$ subunit and trimers containing two (Fig. $5 b$ ). We therefore introduced both cysteines into the same subunit to test whether it was present in the channel adjacent to another copy of itself. We found that $\mathrm{P} 2 \mathrm{X}_{2}$ subunits containing both cysteines ( $\left.\mathrm{P}_{2} \mathrm{X}_{2}[\mathrm{~V} 48 \mathrm{C} / \mathrm{I} 328 \mathrm{C}]\right)$ cannot make intersubunit disulfides in the $\mathrm{P} 2 \mathrm{X}_{2 / 3}$ hetero-oligomer, although this readily occurs in the homo-oligomeric channel (Jiang et al., 2001). Thus coexpression of $\mathrm{P}_{2} \mathrm{X}_{2}[\mathrm{~V} 48 \mathrm{C} / \mathrm{I} 328 \mathrm{C}]$ with wild-type $\mathrm{P} 2 \mathrm{X}_{3}$ subunits gave essentially normal $\mathrm{P}_{2} \mathrm{X}_{2 / 3}$ currents, and these were unaffected by DTT (Fig. 6a). This experiment indicates that the hetero-oligomeric channel does not contain adjacent $\mathrm{P} 2 \mathrm{X}_{2}$ subunits. It also renders unlikely the alternative interpretation that the disulfide formation is interchannel, as distinct from intersubunit within the channel oligomer.

Coexpression of the double cysteinesubstituted $\mathrm{P}_{2} \mathrm{X}_{3}$ subunit with wild-type $\mathrm{P}_{2} \mathrm{X}_{2}$ subunits $\left(\mathrm{P} 2 \mathrm{X}_{3}[\mathrm{~V} 42 \mathrm{C} / \mathrm{I} 319 \mathrm{C}]+\right.$ $\mathrm{P} 2 \mathrm{X}_{2}$ ) provided oligomeric channel currents that were much smaller than control currents, and these were augmented greatly by DTT (Fig. 6b). This experimental result is explained most readily by the assumption that the channel activated by $\alpha \beta$ meATP contains adjacent head-to-tail $\mathrm{P} 2 \mathrm{X}_{3}$ subunits. In other words, both of these two independent experiments indicate that, if the channel is a trimer, then its composition must be $\mathrm{P} 2 \mathrm{X}_{2}\left(\mathrm{P}_{2} \mathrm{X}_{3}\right)_{2}$. If the channel is a tetramer with four subunits arranged head-to-tail around a central pore, then we can conclude that it does not contain adjacent $\mathrm{P}_{2} \mathrm{X}_{2}$ subunits, but it does contain adjacent $\mathrm{P} 2 \mathrm{X}_{3}$ subunits; in other words, only the asymmetrical tetramer $\left(\mathrm{P} 2 \mathrm{X}_{2}-\mathrm{P} 2 \mathrm{X}_{3}-\mathrm{P} 2 \mathrm{X}_{3}-\mathrm{P} 2 \mathrm{X}_{3}\right)$ is allowed. Such an asymmetric arrangement has been proposed recently for the cyclic nucleotide-gated channels (Zheng et al., 2002; Zhong et al., 2002). A hexameric channel would be consistent with our results, but the requirement for adjacent $\mathrm{P}_{2} \mathrm{X}_{3}$ subunits and nonadjacent $\mathrm{P} 2 \mathrm{X}_{2}$ subunits would seem to eliminate the symmetrical hexamer $\left(\mathrm{P} 2 \mathrm{X}_{2}-\mathrm{P} 2 \mathrm{X}_{3}-\mathrm{P} 2 \mathrm{X}_{2}-\mathrm{P} 2 \mathrm{X}_{3}-\mathrm{P} 2 \mathrm{X}_{2}-\mathrm{P} 2 \mathrm{X}_{3}\right)$.

It is easiest to interpret the effects of DTT as indicating that movement of one subunit with respect to another is necessary for channel opening. We have shown previously that a cysteine substituted for $\mathrm{Val}^{48}$ becomes more accessible to methanethiosulfonate when the channel is opened, suggesting an outward movement of TM1 (Jiang et al., 2001). We cannot exclude the possibility, however, that the intersubunit disulfide formation primarily impedes ligand binding. State-dependent disulfide formation has been observed in other channels, both for engineered and naturally occurring cysteines. For example, voltage-gated Shaker potassium channels undergo an outward movement of the S4 segment during channel activation (Larsson et al., 1996; Yusaf et al., 1996) (see also Jiang et al., 2003); depolarization can drive disulfide formation in channels in which a cysteine is placed at the outer end of this segment (L361C) (Aziz et al., 2002). Disulfide formation between endogenous cysteines $\left(\mathrm{Cys}{ }^{481}\right)$ in the C-linker region of subunits of the cyclic nucleotide-gated channel (CNGA1) favors channel opening; these also can form between adjacent, but not opposite, subunits of the tetramer (Rosenbaum and Gordon, 2002). The other channel family that shares with P2X subunits the overall topology of two TMs and a cysteine-rich ectodomain is the epithelial sodium channel/acid-sensing ion channel (ENaC/ASIC) family, some members of which are widely expressed in neurons. The present approach might be applicable also to determine the arrangement of subunits in those channels. On the other hand, it is important not to over-interpret the present data in any structural sense. Our schematics (Figs. 2, 5, 6) depict an arrangement in which three subunits surround a cen- 
tral pore, and it is known that single cysteines introduced at these positions are accessible to water-soluble methane thiosulfonates (Rassendren et al., 1997; Jiang et al., 2001). However, there is no direct evidence that positions these residues on the permeation pathway, and there remains nothing known about the proximity or otherwise of the inner aspects of the membrane-spanning domains (Spelta et al., 2003).

In summary, our results suggest that movement of one P2X subunit relative to another is a key part of gating in both homoand hetero-oligomeric channels. They provide a means to detect adjacent subunits in the receptor oligomer; in the case of the $\mathrm{P}_{2 \mathrm{X}} \mathrm{X}_{2 / 3}$ receptor the channel activated by $\alpha \beta$ meATP has adjacent $\mathrm{P}_{2} \mathrm{X}_{3}$ subunits, but not adjacent $\mathrm{P} 2 \mathrm{X}_{2}$ subunits. These findings contribute to our understanding of the molecular operation of $\mathrm{P} 2 \mathrm{X}$ receptors and will inform our view of the subunit composition and arrangement of the receptors as they are found in nerve cells, including sensory neurons.

\section{References}

Aziz QH, Partridge CJ, Munsey TS, Sivaprasadarao A (2002) Depolarization induces intersubunit cross-linking in a 44 cysteine mutant of the Shaker potassium channel. J Biol Chem 277:42719-42725.

Bean BP (1990) ATP-activated channels in rat and bullfrog sensory neurons: concentration dependence and kinetics. J Neurosci 10:1-10.

Bleehen T, Keele CA (1977) Observations on the algogenic actions of adenosine compounds on the human blister base preparation. Pain 3:367-377.

Burgard EC, Niforatos W, van Biesen T, Lynch KJ, Touma E, Metzger RE, Kowaluk EA, Jarvis MF (1999) P2X receptor-mediated ionic currents in dorsal root ganglion neurons. J Neurophysiol 82:1590-1598.

Clyne JD, Wang LF, Hume RI (2002) Mutational analysis of the conserved cysteines of the rat $\mathrm{P} 2 \mathrm{X}_{2}$ purinoceptor. J Neurosci 22:3873-3880.

Cockayne DA, Hamilton SG, Zhu QM, Dunn PM, Zhong Y, Novakovic S, Malmberg AB, Cain G, Berson A, Kassotakis L, Hedley L, Lachnit WG, Burnstock G, McMahon SB, Ford AP (2000) Urinary bladder hyporeflexia and reduced pain-related behaviour in $\mathrm{P}_{2} \mathrm{X}_{3}$-deficient mice. Nature 407:1011-1015.

Cook SP, Vulchanova L, Hargreaves KM, Elde R, McCleskey EW (1997) Distinct ATP receptors on pain-sensing and stretch-sensing neurons. Nature 387:505-508.

Ding S, Sachs F (1999) Single channel properties of $\mathrm{P}_{2} \mathrm{X}_{2}$ purinoceptors. J Gen Physiol 113:695-720.

Ding Y, Cesare P, Nikitaki D, Wood JN (2000) ATP, P2X receptors and pain pathways. J Auton Nerv Syst 81:289-294.

Dunn PM, Liu M, Zhong Y, King BF, Burnstock G (2000) Diinosine pentaphosphate: an antagonist which discriminates between recombinant $\mathrm{P}_{2} \mathrm{X}_{3}$ and $\mathrm{P} 2 \mathrm{X}_{2 / 3}$ receptors and between two $\mathrm{P} 2 \mathrm{X}$ receptors in rat sensory neurones. Br J Pharmacol 130:1378-1384.

Egan TM, Haines WR, Voigt MM (1998) A domain contributing to the ion channel of ATP-gated $\mathrm{P} 2 \mathrm{X}_{2}$ receptors identified by the substituted cysteine accessibility method. J Neurosci 18:2350-2359.

Ennion SJ, Evans RJ (2002) Conserved cysteine residues in the extracellular loop of the human $\mathrm{P}_{2} \mathrm{X}_{1}$ receptor form disulfide bonds and are involved in receptor trafficking to the cell surface. Mol Pharmacol 61:303-311.

Ennion SJ, Hagan S, Evans RJ (2000) The role of positively charged amino acids in ATP recognition by human $\mathrm{P}_{2} \mathrm{X}_{1}$ receptors. J Biol Chem 275:29361-29367.

Evans RJ, Lewis C, Buell G, Valera S, North RA, Surprenant A (1995) Pharmacological characterization of heterologously expressed ATP-gated cation channels (P2X purinoceptors). Mol Pharmacol 48:178-183.

Grubb BD, Evans RJ (1999) Characterization of cultured dorsal root ganglion neuron P2X receptors. Eur J Neurosci 11:149-154.

Hamilton SG, Warburton J, Bhattacharjee A, Ward J, McMahon SB (2002) ATP in human skin elicits a dose-related pain response which is potentiated under conditions of hyperalgesia. Brain 123:1238-1246.

Honore P, Mikusa J, Bianchi B, McDonald H, Cartmell J, Faltynek C, Jarvis MF (2002a) TNP-ATP, a potent $\mathrm{P}_{2} \mathrm{X}_{3}$ receptor antagonist, blocks acetic acid-induced abdominal constriction in mice: comparison with reference analgesics. Pain 96:99-105.
Honore P, Kage K, Mikusa J, Watt AT, Johnston JF, Wyatt JR, Faltynek CR, Jarvis MF, Lynch K (2002b) Analgesic profile of intrathecal P2X $\mathrm{X}_{3}$ antisense oligonucleotide treatment in chronic inflammatory and neuropathic pain states in rats. Pain 99:11-19.

Jarvis MF, Burgard EC, McGaraughty S, Honore P, Lynch K, Brennan TJ, Subieta A, Van Biesen T, Cartmell J, Bianchi B, Niforatos W, Kage K, Yu $\mathrm{H}$, Mikusa J, Wismer CT, Zhu CZ, Chu K, Lee CH, Stewart AO, Polakowski J, Cox BF, Kowaluk E, Williams M, Sullivan J, Faltynek C (2002) A-317491, a novel potent and selective non-nucleotide antagonist of $\mathrm{P}_{2} \mathrm{X}_{3}$ and $\mathrm{P} 2 \mathrm{X}_{2 / 3}$ receptors, reduces chronic inflammatory and neuropathic pain in the rat. Proc Natl Acad Sci USA 99:17179-17184.

Jiang L-H, Rassendren F, Surprenant A, North RA (2000) Identification of amino acid residues contributing to the ATP-binding site of a purinergic P2X receptor. J Biol Chem 275:34190-34196.

Jiang L-H, Rassendren F, Spelta V, Surprenant A, North RA (2001) Amino acid residues involved in gating identified in the first membrane-spanning domain of the rat $\mathrm{P}_{2} \mathrm{X}_{2}$ receptor. J Biol Chem 276:14902-14908.

Jiang Y, Lee A, Chen J, Ruta V, Cadene M, Chait BT, MacKinnon R (2003) X-ray structure of a voltage-dependent $\mathrm{K}^{+}$channel. Nature 423:33-41.

Khakh BS (2001) Molecular physiology of P2X receptors and ATP signaling at synapses. Nat Rev Neurosci 2:165-174.

Kim M, Spelta V, Sim J, North RA, Surprenant A (2001) Differential assembly of rat purinergic $\mathrm{P} 2 \mathrm{X}_{7}$ receptor in immune cells of the brain and periphery. J Biol Chem 276:23262-23267.

Lalo UV, Pankratov YV, Arndts D, Krishtal OA (2001) Omega-conotoxin GVIA potently inhibits the currents mediated by P2X receptors in rat DRG neurons. Brain Res Bull 54:507-512.

Larsson HP, Baker OS, Dhillon DS, Isacoff EY (1996) Transmembrane movement of the Shaker $\mathrm{K}^{+}$channel S4. Neuron 16:387-397.

Lewis C, Neidhart S, Holy C, North RA, Buell G, Surprenant A (1995) Coexpression of $\mathrm{P} 2 \mathrm{X}_{2}$ and $\mathrm{P} 2 \mathrm{X}_{3}$ receptor subunits can account for ATPgated currents in sensory neurons. Nature 377:432-435.

Newbolt A, Stoop R, Virginio C, Surprenant A, North RA, Buell G, Rassendren F (1998) Membrane topology of an ATP-gated ion channel (P2X receptor). J Biol Chem 273:15177-15182.

Nicke A, Baumert HG, Rettinger J, Eichele A, Lambrecht G, Mutschler E, Schmalzing G (1998) P2X $\mathrm{X}_{1}$ receptors form stable trimers: a novel structural motif of ligand-gated ion channels. EMBO J 17:3016-3028.

Norenberg W, Illes P (2000) Neuronal P2X receptors: localisation and functional properties. Naunyn Schmiedebergs Arch Pharmacol 362:324-339.

North RA (2002) Molecular physiology of P2X receptors. Physiol Rev 82:1013-1067.

Petruska JC, Napaporn J, Johnson RD, Cooper BY (2002) Chemical responsiveness and histochemical phenotype of electrophysiologically classified cells of the adult rat dorsal root ganglion. Neuroscience 115:15-30.

Radford KM, Virginio C, Surprenant A, North RA, Kawashima E (1997) Baculovirus expression provides direct evidence for heteromeric assembly of $\mathrm{P} 2 \mathrm{X}_{2}$ and $\mathrm{P} 2 \mathrm{X}_{3}$ receptors. J Neurosci 17:6529-6533.

Rassendren F, Buell G, Newbolt A, North RA, Surprenant A (1997) Identification of amino acid residues contributing to the pore of a $\mathrm{P} 2 \mathrm{X}$ receptor. EMBO J 16:3446-3454.

Rosenbaum T, Gordon SE (2002) Dissecting intersubunit contacts in cyclic nucleotide-gated ion channels. Neuron 33:703-713.

Souslova V, Cesare P, Ding Y, Akopian AN, Stanfa L, Suzuki R, Carpenter K, Dickenson A, Boyce S, Hill R, Nebenuis-Oosthuizen D, Smith AJ, Kidd EJ, Wood JN (2000) Warm-coding deficits and aberrant inflammatory pain in mice lacking P2X 3 receptors. Nature 407:1015-1017.

Spelta V, Jiang LH, Surprenant A, North RA (2002) Kinetics of antagonist actions at rat $\mathrm{P} 2 \mathrm{X}_{2 / 3}$ heteromeric receptors. $\mathrm{Br} \mathrm{J}$ Pharmacol 135:1524-1530.

Spelta V, Jiang LH, Bailey RJ, Surprenant A, North RA (2003) Interaction between cysteines introduced into each transmembrane domain of the rat $\mathrm{P} 2 \mathrm{X}_{2}$ receptor. Br J Pharmacol 138:131-136.

Stoop R, Thomas S, Rassendren F, Kawashima E, Buell G, Surprenant A, North RA (1999) Contribution of individual subunits to the multimeric P2 $\mathrm{X}_{2}$ receptor: estimates based on methanethiosulfonate block at T336C. Mol Pharmacol 56:973-981.

Thomas S, Virginio C, North RA, Surprenant A (1998) The antagonist 
trinitrophenyl-ATP reveals coexistence of distinct P2X receptor channels in rat nodose neurones. J Physiol (Lond) 509:411-417.

Torres GE, Egan TM, Voigt MM (1999a) Hetero-oligomeric assembly of P2X receptor subunits. Specificities exist with regard to possible partners. J Biol Chem 274:6653-6659.

Torres GE, Egan TM, Voigt MM (1999b) Identification of a domain involved in ATP-gated ionotropic receptor subunit assembly. J Biol Chem 274:22359-22365.

Ueno S, Tsuda M, Iwanaga T, Inoue K (1999) Cell type-specific ATPactivated responses in rat dorsal root ganglion neurons. Br J Pharmacol 126:429-436.

Virginio C, Robertson G, Surprenant A, North RA (1998) Trinitrophenylsubstituted nucleotides are potent antagonists selective for $\mathrm{P} 2 \mathrm{X}_{1}, \mathrm{P}_{2} \mathrm{X}_{3}$, and heteromeric $\mathrm{P} 2 \mathrm{X}_{2 / 3}$ receptors. Mol Pharmacol 53:969-973.
Werner P, Seward EP, Buell GN, North RA (1996) Domains of P2X receptors involved in desensitization. Proc Natl Acad Sci USA 93:15485-15490.

Yusaf SP, Wray D, Sivaprasadarao A (1996) Measurement of the movement of the S4 segment during the activation of a voltage-gated potassium channel. Pflügers Arch 433:91-97.

Zheng J, Trudeau MC, Zagotta WN (2002) Rod cyclic nucleotide-gated channels have a stoichiometry of three CNGA1 subunits and one CNGB1 subunit. Neuron 36:891-896.

Zhong H, Molday LL, Molday RS, Yau KW (2002) The heteromeric cyclic nucleotide-gated channel adopts a 3A:1B stoichiometry. Nature 420:193-198.

Zhong Y, Dunn PM, Bardini M, Ford AP, Cockayne DA, Burnstock G (2001) Changes in $\mathrm{P} 2 \mathrm{X}$ receptor responses of sensory neurons from $\mathrm{P}_{2} \mathrm{X}_{3}$ deficient mice. Eur J Neurosci 14:1784-1792. 